\title{
Flow Injection Biosensor System for 2,4-Dichlorophenoxyacetate Based on a Microbial Reactor and Tyrosinase Modified Electrode
}

\author{
Mitsuhiro Shimojo, Kei Amada, Hidekazu Koya and Mitsuyasu Kawakami \\ Fukuoka Institute of Technology \\ Japan
}

\section{Introduction}

Synthetic chlorinated organic compounds have been used extensively as herbicides and pesticides and the contamination of ecosystems with these compounds has stimulated great interest in investigation of these frequently toxic or bioaccumulatable compounds. 2,4-Dichlorophenoxyacetate (2,4-D), one of these compounds, is a synthetic phytohormone that has been widely used as a herbicide for controlling broadleaf weeds, and huge amount of 2,4-D has been released into the environment. 2,4-D is known, on the other hand, to be susceptible to rapid biological degradation in natural environments, and has been used as a model for genetic and biochemical study on the chloroaromatic degradation. A number of its degrading bacteria have been isolated worldwide from a variety of environments and extensively examined on a molecular basis (Amy et al., 1985; Sinton et al., 1986; Perkins et al., 1990; Fulthorpe et al., 1992, 1995; Ka et al., 1994; Tonso et al., 1995; Top et al., 1995; Maltseva et al., 1996; Suwa et al., 1996; Vallaeys et al., 1996; Kamagata et al., 1997; Cavalca et al., 1999; Laemmli et al., 2000; Itoh et al., 2002). One of the most extensively studied strain is Ralstonia eutrophus JMP134, which carries a 2,4-D-degrading gene cluster on the transmissible plasmid pJP4 (Don \& Pemberton, 1981; Neilson et al., 1992; Fukumori \& Hausinger, 1993a; Laemmli et al., 2000).

On the other hand, reliable determination of 2,4-D is indispensable to investigate its biological degradation. A biosensor is a device utilizing a biological sensing element, and a variety of biosensors for 2,4-D detection have been developed (Table 1). Most of sensors reported so far, however, can be classified into either immunoassay or immunoenzymatic assay. They are based on the specific interaction between 2,4-D (antigen) and its antibody. These biosensors have been demonstrated to show very high sensitivities (e.g. the lower detection limit of less than $1 \mu \mathrm{g} / \mathrm{L}$ ), while these assays are generally said to be somewhat cumbersome to perform and require considerably expensive reagents. A biosensor based on the inhibition of catalytic activity of enzyme alkaline phosphatase in the presence of 2,4-D has been also proposed and a detection limit of $0.5-6 \mu \mathrm{g} / \mathrm{L}$ has been obtained. The enzyme inhibition effect has been also observed for another pesticide, indicating the analyte selectivity of the sensor to be not expected. On the other hand, very few attempts have been made on the biosensor employing microorganisms as the sensing component. 


\begin{tabular}{|c|c|c|c|}
\hline Bioelement & Transducer & Principle/Comment & Reference \\
\hline \multirow[t]{11}{*}{ antibody } & SPR & immunoassay/ resonance angle & Starodub et al., 2005 \\
\hline & electrode & affinity sensor /conductance & Hianiketal., 1998,1999 \\
\hline & luminometer & $\begin{array}{l}\text { immunoenzymatic assay/ } \\
\text { chemiluminescence }\end{array}$ & Rubtsova etal., 1997 \\
\hline & QCM & immunoassay/ piezoelectricity & Horacek et al., 1997, 2000 \\
\hline & TIRFa fibre & immunoassay/optical & Mosiello et al., 1997 \\
\hline & electrode & $\begin{array}{l}\text { immunoassay/ bi-enzyme amplifier, } \\
\text { amperometry }\end{array}$ & Bier et al., 1997 \\
\hline & electrode & $\begin{array}{l}\text { immunoassay/ enzymaticinhibition, } \\
\text { amperometry }\end{array}$ & Medyantseva et al., 1997 \\
\hline & electrode & $\begin{array}{l}\text { immunoenzymatic assay/ } \\
\text { amperometry }\end{array}$ & Trau et al., 1997 \\
\hline & electrode & $\begin{array}{l}\text { immunoenzymatic assay/ } \\
\text { potentiometry }\end{array}$ & Piras et al., 1996 \\
\hline & electrode & $\begin{array}{l}\text { immunoenzymatic assay/ } \\
\text { amperometry }\end{array}$ & Skladal et al., 1995 \\
\hline & electrode & $\begin{array}{l}\text { immunoenzymatic assay/ } \\
\text { amperometry }\end{array}$ & Kalab et al., 1995 \\
\hline enzyme & electrode & $\begin{array}{l}\text { enzymatic inhibition/ } \\
\text { amperometry, voltammometry }\end{array}$ & Mazzei et al., 2004 \\
\hline $\begin{array}{l}\text { micro- } \\
\text { organism }\end{array}$ & $\mathrm{O}_{2}$ electrode & respiration activity/ A.eutrophus & Beyersdorf-Radeck et al., 1993 \\
\hline
\end{tabular}

(a: total internal reflection fluorescence)

Table 1. Biosensors for 2,4-D analysis.

\section{Principle of the present sensor system}

\subsection{2,4-D degrading microorganisms}

As described above, a number of 2,4-D degrading bacteria have been isolated worldwide from varying environments. Bacteria capable of degrading 2,4-D are of general importance for the preservation of the environment, and microbial degradation with such bacteria has been extensively studied as a model for decomposition of hazardous chloroaromatic compounds (Häggblom,1990, 1992; van der Meer et al., 1992).

A microbial 2,4-D biosensor has been developed by employing a layer of Alcaligenes eutrophus (Ralstonia eutrophus) JMP134 (Table 1). Concerning to this sensor, the concentration of 2,4-D has been determined by monitoring the oxygen consumption with an oxygen electrode since the bacterium requires oxygen for the degradation of the xenobiotic. However, this approach can be disturbed by the presence of other oxygenases in a microbial cell. 
Recent physiological and evolutional studies have demonstrated that these 2,4-D-degrading bacteria could be categorized into three groups (Ka et al., 1994; Kamagata et al., 1997; Kitagawa et al., 2002; Itoh et al., 2004). Most of the 2,4-D-degrading bacteria isolated from human-disturbed sites include copiotrophic and fast-growing genera in the $\beta$ and $\gamma$ subdivisions of Proteobacteria, which has been classified as class I 2,4-D degraders. The degradation pathway of 2,4-D has been extensively characterized with Ralstonia eutrophus JMP134, one of the class I degraders (Don et al., 1985; Streber et al., 1987; Perkins et al., 1990). Degradation of 2,4-D in this class of degraders is considered to be initiated by cleavage of the ether linkage to yield 2,4-dichlorophenol (2,4-DCP), which is then hydroxylated to 3,5-dichlorocatechol (3,5-DCC), followed by ring cleavage (Fig. 1).<smiles>O=C([O-])Oc1ccc(Cl)cc1Cl</smiles>

2,4-D<smiles>Oc1ccc(Cl)cc1Cl</smiles>

2,4-DCP<smiles>Oc1cc(Cl)cc(Cl)c1O</smiles><smiles>O=C(O)c1cc(Cl)cc(Cl)c1</smiles>

3,5-DCC

\section{2,4-Dichloromuconate}

Fig. 1. Aerobic degradation pathway of 2,4-D for class I degraders.

\subsection{Biosensors detecting metabolic intermediates}

It is noteworthy that the phenolic and the catecholic compounds are produced as the first and the second degradation products, respectively, in the pathway described above, while these compounds are metabolized finally to carbon dioxide. This implies that the concentration of 2,4-D might be estimated by determining these intermediates with a sensing device. Microbial biosensors based on the determination of the metabolic intermediate have not been reported for 2,4-D, while such a type of whole cell amperometric biosensors have been reported for $p$-nitrophenol (Lei et al., 2004; Mulchandani et al., 2005). A tyrosinase-modified electrode is one of effective transducers for phenols or catechols detection, for which active studies have been made on the development of highly efficient tyrosinase electrodes (for example, Notsu \& Tatsuma, 2004; Mailley et al., 2004; Stanca \& Popescu, 2004; Gutés et al., 2005; Carralero Sanz et al., 2005; Liu et al., 2005). Developments of flow injection analysis with tyrosinase electrode have been also attempted (Dall' Orto et al., 1999; Li \& Tan, 2000; Notsu et al., 2002; Serra et al., 2003).

Then, in the present work a novel biosensor system was constructed with a fixed-bed reactor packed with immobilized microbes and a tyrosinase-modified graphite electrode. This sensor system monitors phenolic and catecholic compounds produced in the first two steps by the microbial degradation of 2,4-D.

\section{Construction of sensor system}

\subsection{Isolation of 2,4-D-degrading bacteria and confirmation of degradation}

In order to isolate 2,4-D-degrading bacteria, soil samples were collected from various environments such as mountains, farmlands, riversides, and industrial areas in Northern Kyushu. They were mixed with a mineral salt (MS) medium $\left(0.5 \mathrm{~g} \mathrm{~K}_{2} \mathrm{HPO}_{4}, 0.5 \mathrm{~g} \mathrm{KH} \mathrm{PO}_{4}\right.$, 
$0.25 \mathrm{~g} \mathrm{NH}_{4} \mathrm{NO}_{3}, 0.002 \mathrm{~g} \mathrm{NaMoO}_{4} \bullet 2 \mathrm{H}_{2} \mathrm{O}, 0.001 \mathrm{~g} \mathrm{FeSO}_{4} \bullet 7 \mathrm{H}_{2} \mathrm{O}$, and $0.001 \mathrm{~g} \mathrm{MnSO}_{4} \bullet 7 \mathrm{H}_{2} \mathrm{O}$ per liter) containing 2,4-D (0.005 g) as the sole carbon source, and enrichment culture was performed at $30^{\circ} \mathrm{C}$ for $7 \mathrm{~d}$. The culture broth was centrifuged, and the concentration of 2,4$\mathrm{D}$ in the supernatant was measured using a spectrophotometer at $284 \mathrm{~nm}$ and a highperformance liquid chromatography (HPLC) (LaChrom series, Hitachi, Tokyo, Japan). The culture broths with decreased 2,4-D concentration were then transferred to basal agar plates containing 2,4-D. Finally, we could obtain 11 isolates. 2,4-D degradation ability of the strains was confirmed by the decrease in the amount of remaining substrate, which was measured with HPLC. Identification of the strains was performed by $16 S$ rDNA sequence analysis. Among them the bacterium identified as Ralstonia sp., which showed relatively high degradation capability and rapid growth in a medium containing 2,4-D as a sole carbon source, was employed for the sensor system. The strain was found to have $97 \%$ sequence similarity to Ralstonia sp. JMP134.
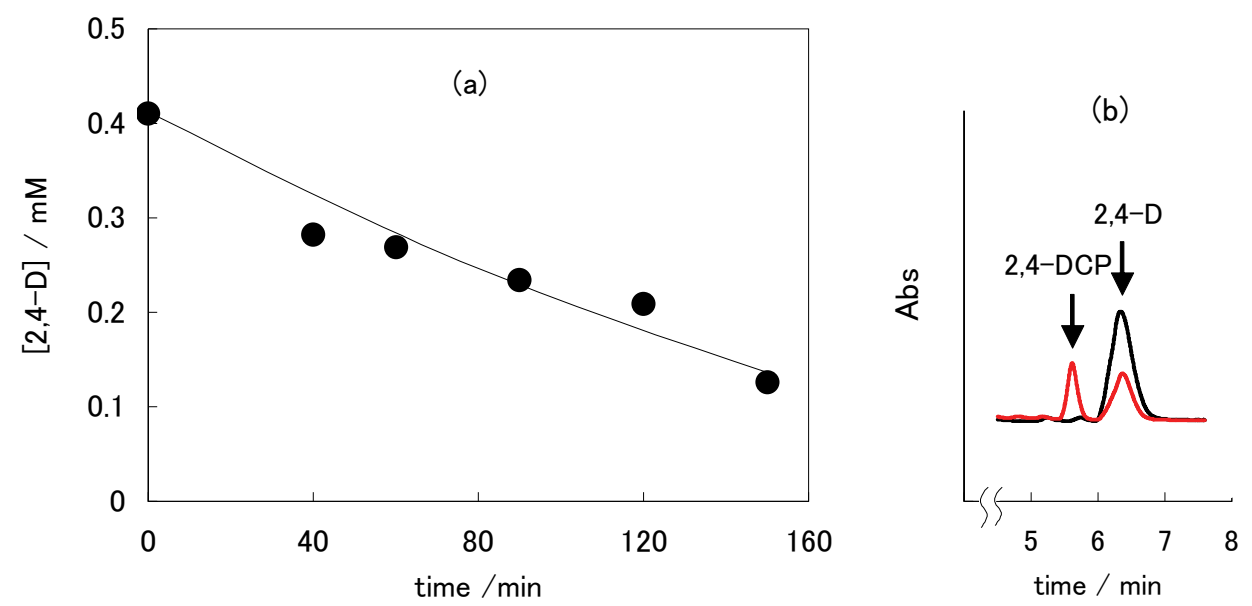

Fig. 2. Time course of 2,4-D concentration (a) and an example of chromatogram (b) obtained for degradation experiment with cell suspension; reaction time -: $0 \mathrm{~min},-150 \mathrm{~min}$.

The 2,4-D degradation activity of the strain was examined by monitoring the reduction of the amount of remaining substrate in a culture. The microorganism was grown aerobically in Luria-Bertani (LB) medium ( $\mathrm{NaCl}, 10$; Tryptone, 10; Yeast Extract, $5 \mathrm{~g} / \mathrm{L}$ ) containing 0.10 $\mathrm{g} / \mathrm{L}(0.4 \mathrm{mM}) 2,4-\mathrm{D}$ at $30^{\circ} \mathrm{C}$ for $20 \mathrm{~h}$ to a late-exponential phase. The cells were harvested by centrifugation and washed thoroughly with sterile saline, which was then resuspended in the same solution. Degradation experiment initiated by transferring a fixed amount of the cell suspension into MS medium supplemented with 2,4-D $(0.10 \mathrm{~g} / \mathrm{L})$, was performed at $30^{\circ} \mathrm{C}$ on a reciprocating shaker. The $2,4-\mathrm{D}$ content was measured periodically with HPLC.

The time course of decrease in 2,4-D concentration and an example of HPLC chromatogram are shown in Fig. 2(a) and (b), respectively. It is seen that the 2,4-D content decreases smoothly with increasing the incubation time. Further, a decrease in peak-height for 2,4-D and an appearance of 2,4-DCP peak were confirmed by comparing the chromatograms obtained at the incubation time of 0 and $150 \mathrm{~min}$, while variation of the amount of 2,4-DCP could not be followed accurately since most of their peaks were too small. 


\section{2 immobilization of microbes}

Silica gel particles (Wako Gel type G, 300-600 $\mu \mathrm{m}$, Wako Pure Chemical Industries Ltd., Tokyo, Japan) were used as the carrier for immobilization of bacteria. LB medium containing $0.05 \mathrm{~g} / \mathrm{L} \mathrm{2,4-D}$ was used for cultivation and immobilization. A continuous flow reactor was constructed with a glass column $(13 \mathrm{~mm} \phi \times 80 \mathrm{~mm})$ in which silica gel particles were packed. A sterile medium $(100 \mathrm{~mL})$ prepared in a reservoir $(250 \mathrm{~mL}$ - glass bottle) was circulated with a peristaltic pump at a flow rate of $1 \mathrm{~mL} / \mathrm{min}$, followed by inoculation with the pre-incubated culture $(1 \mathrm{~mL})$. After the incubation at $30^{\circ} \mathrm{C}$ for $72 \mathrm{~h}$ the cells were harvested and washed thoroughly with $0.1 \mathrm{M}$ sodium phosphate buffer (PBS; pH 7.0). Then, the immobilized microbes particles were suspended in sterile $0.9 \% \mathrm{NaCl}$ solution and transferred into a centrifuge tube. The immobilized microbes particles thus obtained were stored in a refrigerator for at least $24 \mathrm{~h}$ before use.

\subsection{Instrumentation}

A schematic diagram of the reactor type biosensor system is illustrated in Fig. 3. The system consists of a peristaltic pump (model 7553-80, Masterflex, Cole-Parmer Instrument Co., Vernon Hills, IL, USA), a sample injector with a $50 \mu \mathrm{L}$ loop, a 6-way valve, a microbial reactor, and a flow cell. Two PTFE rotary valves (Rheodyne, Rhonert Park, CA, USA) were used as the injector and the valve. The 6-way valve was switched to the reactor port when the response to 2,4-D was measured. On the other hand, the valve was switched to the flow cell port when the sensitivity of enzyme electrode was checked. The microbial reactor, flow cell, and carrier reservoir were placed in an incubator maintained at $30^{\circ} \mathrm{C}$.

Enlarged schematics of the microbial reactor and the flow cell are illustrated in Figs. 4(a) and $4(\mathrm{~b})$, respectively. The parts of the reactor body were made of a PTFE rod $(60 \mathrm{~mm} \phi)$. Silica gel particles with immobilized microbes were packed in the cell holder $(20 \mathrm{~mm} \phi)$ and supported with two pieces of SUS mesh screen. In the present work the cell holders of 3 and $12 \mathrm{~mm}$ in height $(H)$ were used. The flow cell was made of a PTFE sheet and a $3 \mathrm{~mm}$ - thick silicone gasket. The cell volume was estimated to be about $0.7 \mathrm{~mL}$. A platinum plate $(20 \times 10 \times 0.5 \mathrm{~mm})$ and an $\mathrm{Ag} / \mathrm{AgCl}$ electrode $(1 \mathrm{~mm} \phi)$ were used as the auxiliary and the reference electrode, respectively. The microbial reactor and the flow cell were kept at $30^{\circ} \mathrm{C}$ in an incubator.

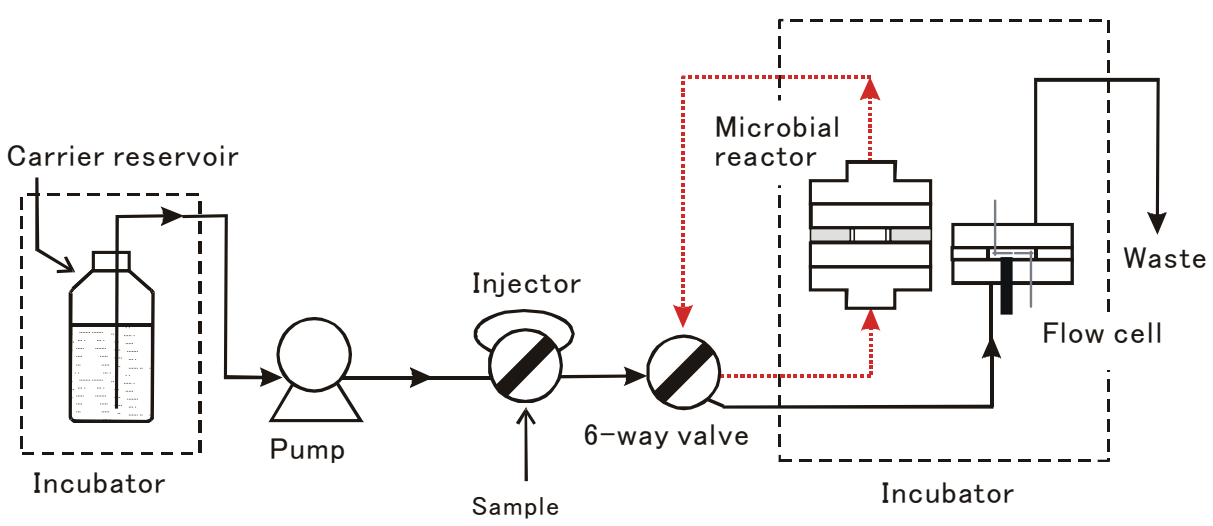

Fig. 3. Schematic diagram of the 2,4-D sensor system. 
(a)

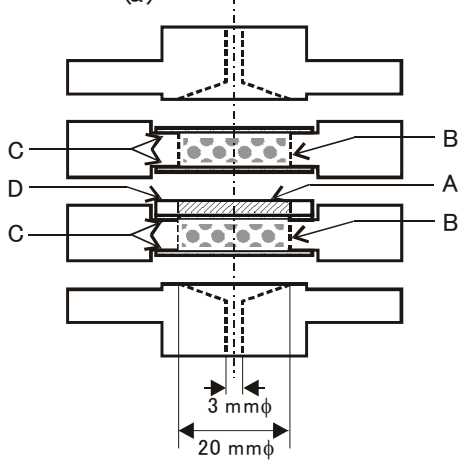

(b)

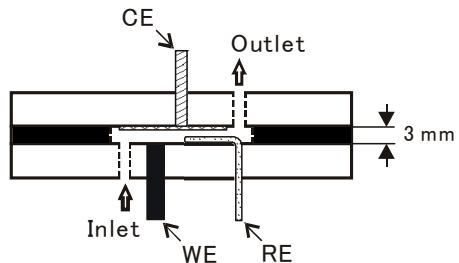

Fig. 4. Schematics of the microbial reactor (a) and the flow cell (b). A: immobilized microbe, B: glass beads, C: SUS mesh screen, D: immobilized microbes holder.

Graphite electrodes were polished with $0.1 \mu \mathrm{m}$ alumina powder, and rinsed thoroughly with deionized water. Then, these electrodes were sonicated in acetone and deionized water successively, and allowed to dry at room temperature. Tyrosinase (from mushroom, E.C. 1.14.18.1) was purchased from Sigma (St. Louis, MO, USA) and used without further purification. The enzyme activity was determined by using tyrosine as a substrate. An enzyme solution was prepared by dissolving $3.0 \mathrm{mg}$ tyrosinase in $1.0 \mathrm{~mL}$ PBS $(0.1 \mathrm{M}$; pH 7.0). The $20 \mu \mathrm{L}$ of the tyrosinase solution (about 36 units) were deposited with a microsyringe on a graphite electrode surface, and allowed to dry at $4^{\circ} \mathrm{C}$. Finally, the $20 \mu \mathrm{L}$ of Nafion solution (Sigma-Aldrich, $0.5 \%$ ) were deposited on the tyrosinase-coated electrode surface, and allowed to dry at $4^{\circ} \mathrm{C}$ for an overnight. The enzyme electrodes were stored in PBS (0.1 M, pH 7.0) at $4^{\circ} \mathrm{C}$ when not in use.

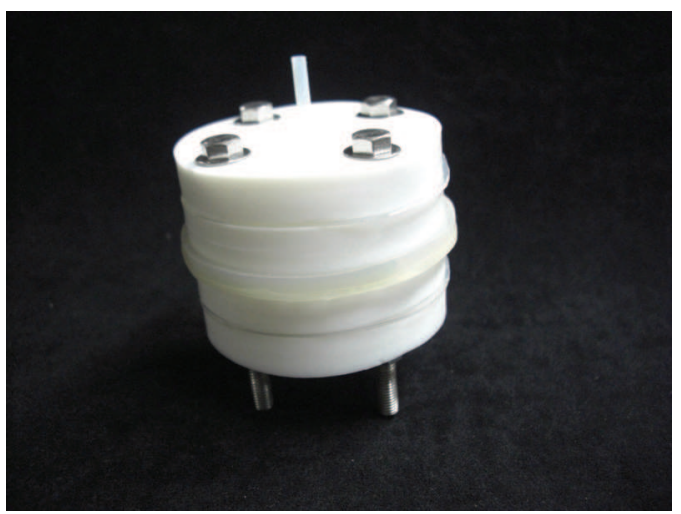

(a)

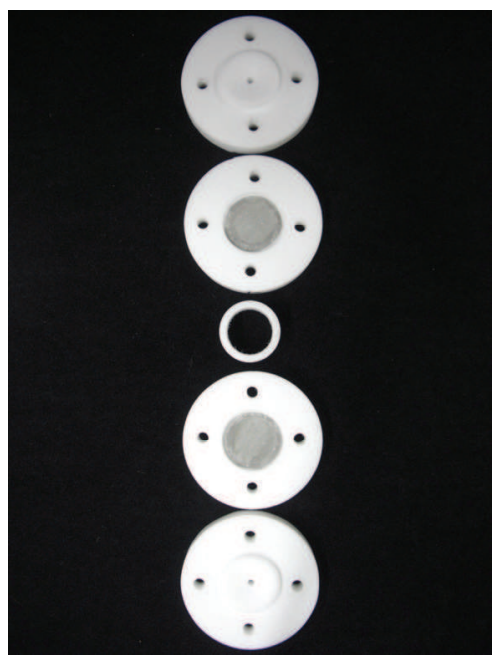

(b)

Fig. 5. Photographs of the reactor (a) and its parts (b). 


\subsection{Response measurement}

$0.1 \mathrm{M}$ PBS (pH 6.0, 6.5, and 7.0) containing $0.1 \mathrm{M} \mathrm{NaCl}$ was used as the mobile phase. The carrier reservoir was hold in an incubator kept at $30^{\circ} \mathrm{C}$, and the carrier solution was made to flow through the system at a constant flow rate. Amperometric measurements for the sensor system were made by applying a given potential on the working electrode (enzyme electrode) with a potentiostat (model HECS 318C, Huso Electro Chemical Systems, Kawasaki, Japan) connected to a personal computer. 2,4-D, 2,4-DCP and 3,5-DCC standard solutions for flow injection measurements were prepared with the PBS used as the mobile phase. The microbial reactor was filled with the mobile phase solution employed and left at $30^{\circ} \mathrm{C}$ when not used for the measurements.

\section{Performance and characteristics of sensor system}

\subsection{Sensor response of the tyrosinase-modified electrode}

The enzyme tyrosinase catalyses two reactions; the hydroxylation of phenols to give catechols and the oxidation of catechols to o-quinones in the presence of oxygen. The determination of phenolic compounds with the tyrosinase modified electrodes can be based either on the electrochemical oxidation of catechols or the electrochemical reduction of quinones.
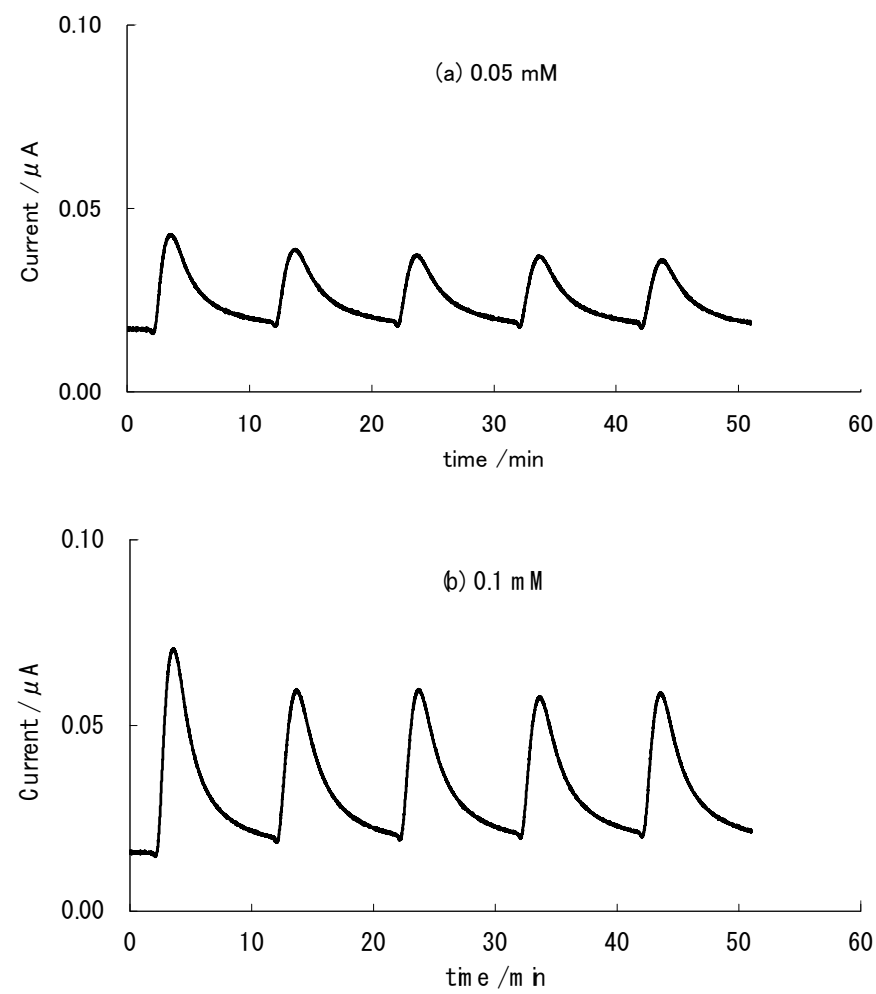

Fig. 6. Diagrams of amperometric responses obtained with the flow cell for successive injections of (a) $0.05 \mathrm{mM}$ and (b) $0.1 \mathrm{mM} \mathrm{2,4-DCP} \mathrm{(pH} \mathrm{6.5;} H=3 \mathrm{~mm}$; flow rate $1.0 \mathrm{~mL} / \mathrm{min}$ ). 
The oxidation on the electrode occurs at a relatively high potential, while the reduction at a low potential. Then, effects of the applied potential on the amperometric response for the tyrosinase electrode were first examined by applying a potential of $\pm 0,+0.2$, and $+0.5 \mathrm{~V}$ (vs. $\mathrm{Ag} / \mathrm{AgCl}$ ). In this case the microbial reactor was bypassed and the substrate was sent directly to the flow cell. Consequently, the magnitudes of both the response and the residual currents were found to be affected seriously by the electrode potential, and the best sensitivity and baseline stability were obtained at $+0.5 \mathrm{~V}$ as compared with those at \pm 0 and $+0.2 \mathrm{~V}$. Then the potential was fixed at $+0.5 \mathrm{~V}$ and anodic output currents were monitored throughout the measurements.

Examples of amperometric responses obtained with the tyrosinase-modified electrode for successive injections of 2,4-DCP standard solutions with PBS ( $\mathrm{pH} 7.0$ ) containing $0.1 \mathrm{M} \mathrm{NaCl}$ as the mobile phase at the applied potential of $0.5 \mathrm{~V}$ and the flow rate of $1.0 \mathrm{~mL} / \mathrm{min}$ are shown in Fig. 6(a) and 6(b). With an injection of the substrate, as it can be seen, an anodic peak was obtained as the electrochemical response. Both the peak current (height) and the peak area were found to increase with the concentration of 2,4-DCP injected. The average peak area determined for quintuplicate output signals was used to depict the calibration curve (Fig. 7). It can be seen that there exists not appreciable difference between the sensitivity for 2,4-DCP and that for 3,5-DCC. The lower detection limit for both compounds was $0.01 \mathrm{mM}$.

On the other hand, appreciable response current could not be observed when $1.0 \mathrm{mM}$ 2,4-D standard solutions injected did not passthrough the microbial reactor and was sent directly to the tyrosinase electrode. This implies that 2,4-D is not detected electrochemically with the enzyme-modified electrode and either 2,4-DCP or 3,5-DCP is not significantly contained in the 2,4-D standard solution as an impurity.

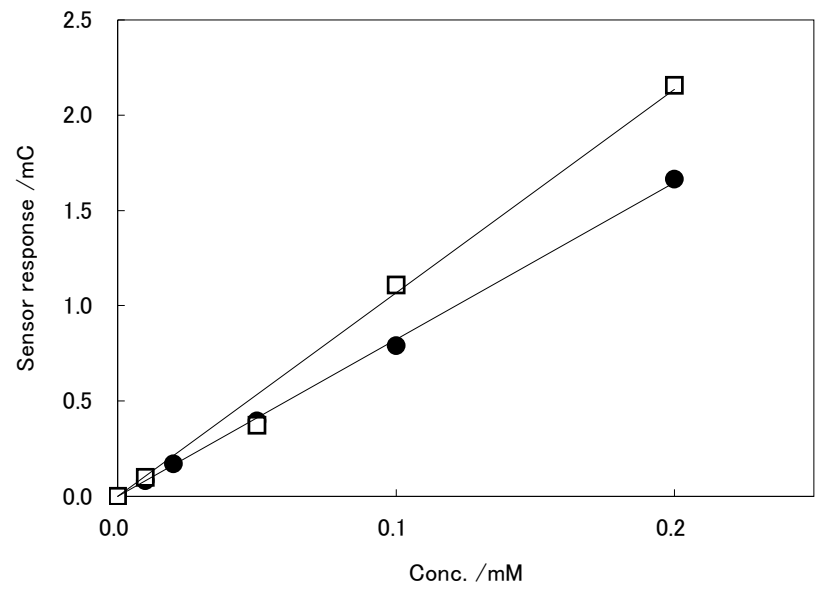

Fig. 7. Calibration plots for 2,4-DCP $(\bullet)$ and 3,5-DCC ( $\square$ ) determined with the flow cell.

\subsection{Performance of 2,4-D biosensor system}

The 2,4-D degradation activity of the strain was examined, as described before, using suspension of Ralstonia sp. in MS medium containing 2,4-D as a sole carbon source. In the 
case of immobilized cells, however, it is necessary to take into account the possibility of adsorption of the substrate by carrier particles employed for immobilization. Then, a fixedbed reactor was constructed by replacing the glass column $(8 \mathrm{~mm} \phi \times 50 \mathrm{~mm})$ of the system utilized for cell immobilization. After the immobilized cells or bare silica gel particles were packed into the column, a sterile MS medium $(100 \mathrm{~mL})$ containing 2,4-D prepared in a reservoir was circulated at a flow rate of $1.5 \mathrm{~mL} / \mathrm{min}$ at $30^{\circ} \mathrm{C}$ for $12 \mathrm{~h}$. The 2,4 -D content was analyzed periodically with HPLC.

The time course of decrease in 2,4-D concentration observed for the immobilized microbial reactor is shown in Fig. 8. It is seen that 2,4-D is appreciably adsorbed by silica gel particles and its concentration is reduced to almost one-half its initial value for $12 \mathrm{~h}$. The amount of adsorbed 2,4-D would decrease when microorganisms are immobilized onto the carrier particles. In the assay of the culture, on the other hand, the signal of 2,4-DCP could not be observed in the chromatogram. This may be due to the possibilities of adsorption of 2,4-DCP by the solid carrier and/or limitation of the detector of HPLC. Moreover, the initial rates of the decrease in 2,4-D content for both cases could be considered to be almost the same, suggesting that the degradation and the adsorption of 2,4-D might occur competitively when the substrate and the immobilized microbe particles come into contact in the reactor. Then, in order to eliminate the effect of adsorption on the silica gel surface, successive injections of the substrate was continued until stable response was obtained in the amperometric measurements.

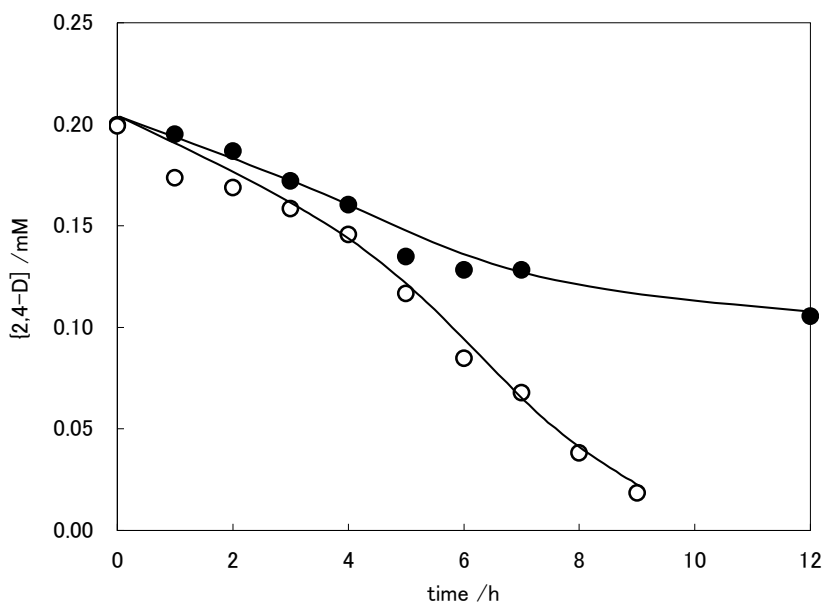

Fig. 8. Time course of 2,4-D concentration obtained for the fixed bed reactor packed with immobilized cells $(\circ)$ and carrier particles alone $(\bullet)$.

Fig. 9 shows an example of amperometric response obtained with the sensor system employing Ralstonia sp. for which the immobilized cell holder of $3 \mathrm{~mm}$ in height was used. Using $0.1 \mathrm{M}$ PBS (pH 6.5) containing $0.1 \mathrm{M} \mathrm{NaCl}$ as the mobile phase, $1.0 \mathrm{mM}$ 2,4-D was injected successively at the flow rate of $1.0 \mathrm{~mL} / \mathrm{min}$. An anodic peak was observed each time with an injection of the substrate. It can be also seen not to take more than $10 \mathrm{~min}$ for each measurement. Response current could not be observed, as described before, when the substrate did not pass through the microbial reactor. This indicates the response of the 
sensor system to be induced by the electrode reaction of electrochemically active substances such as phenolic and/or catecholic compounds, which could be produced by the microbial degradation of 2,4-D in the reactor. Then, the average peak area determined for triplicate output signals was used as the response of the sensor system.

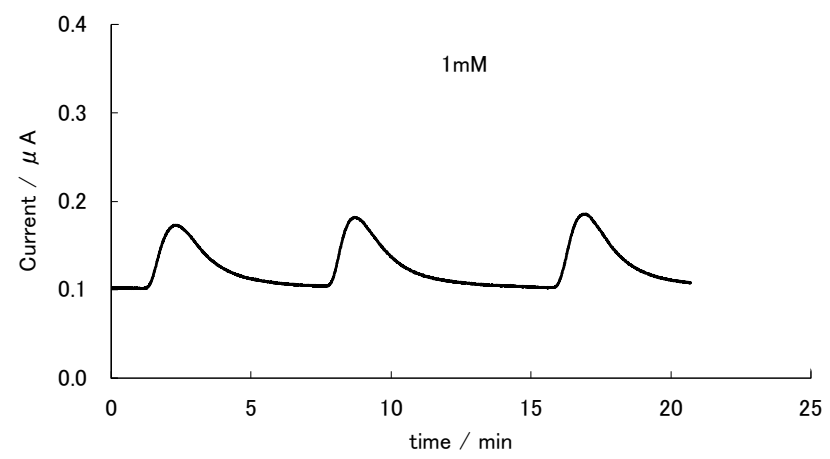

Fig. 9. Diagram of amperometric response obtained with the sensor system for successive injections of 2,4-D standard solution ( $\mathrm{pH} 6.5 ; \mathrm{H}=3 \mathrm{~mm}$; flow rate $1.0 \mathrm{~mL} / \mathrm{min}$ ).

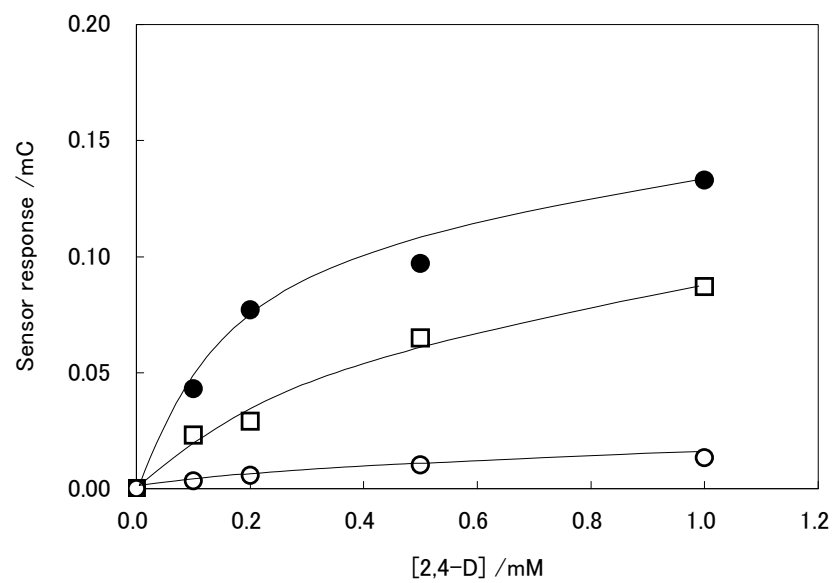

Fig. 10. Effect of the $\mathrm{pH}$ of carrier solution on the response of sensor system for 2,4-D; $(\bullet) \mathrm{pH}$ 7.0, () $\mathrm{pH} 6.5$, (०) $\mathrm{pH} 6.0$ (H=3 $\mathrm{mm}$; flow rate $1.0 \mathrm{~mL} / \mathrm{min})$.

The effect of the $\mathrm{pH}$ of mobile phase solution on the response of sensor system was investigated using carrier solutions of $\mathrm{pH} \mathrm{6.0,6.5} \mathrm{and} \mathrm{7.0.} \mathrm{The} \mathrm{results} \mathrm{are} \mathrm{depicted} \mathrm{in} \mathrm{Fig.} 10$. The sensor response can be seen to increase with increasing $\mathrm{pH}$ of carrier solution in the range applied here. It has been reported that 2,4-dichlorophenoxyacetate/ $\alpha$-ketoglutarate dioxygenase, the enzyme responsible for the first step of degradation pathway for 2,4-D exhibits maximum activity at $\mathrm{pH}$ 6.5-7 (Fukumori \& Hausinger, 1993b). On the other hand, the sensitivity of the tyrosinase-modified electrode for 2,4-DCP has been also observed to exibit almost the same $\mathrm{pH}$ dependence (the data are not shown). The $\mathrm{pH}$ dependence of the 
responsibility of present sensor system would result from the synergetic effect of the $\mathrm{pH}$ dependencies of enzyme activities for 2,4-D degradation and product detection.

Effect of the height of immobilized microbes bed on the responsibility of sensor system is shown in Fig. 11. It is seen that the response obtained by using the bed of $12 \mathrm{~mm}$ in height is considerably enhanced when compared with that observed with the bed of $3 \mathrm{~mm}$ in height. As the immobilized microbes bed becomes higher both the residence time and the amount of biocatalyst in the reactor increase. It is reasonable that the amount of degradation product increase with increasing the height of biocatalyst bed. Thus, employment of higher bed in the reactor is considerably effective to enhance the sensitivity of the sensor system, while it has been found to require longer time for a measurement (about $20 \mathrm{~min}$ at flow rate of $1.0 \mathrm{~mL} / \mathrm{min})$.

The flow rate of carrier solution has been also found to considerably affect the sensor response. Calibration plots obtained by the sensor system for 2,4-D with different flow rates are shown in Fig. 12. As can be seen from the figure, the sensitivity of the sensor system was appreciably enhanced by lowering the flow rate. The residence time in the reactor increases with decreasing the flow rate, which exerts almost the same effect as that of the height of biocatalyst bed. It is also confirmed that lowering the flow rate enhances the sensitivity of tyrosinase-modified electrode in the flow cell. The result obtained here is considered to be induced by combined effects of the flow rate on the reactor and the flow cell. In any event, it is evident that the sensitivity of sensor system can be improved by making the carrier solution to flow at a reduced rate, while it takes longer time for a measurement.

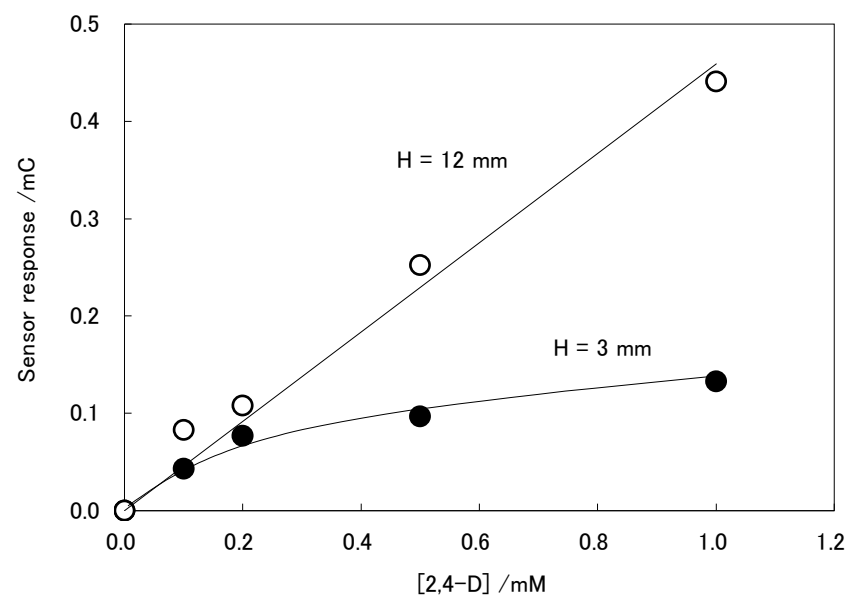

Fig. 11. Effect of the height of immobilized microorganisms bed on the response of sensor system for 2,4-D (pH 7.0; flow rate $1.0 \mathrm{~mL} / \mathrm{min}$ ).

The sensitivity of the sensor system was found to be almost unchanged during the measurements for one week when the reactor and the tyrosinase electrode were stored as described before. The lower detection limit and the detection range at the present state were $0.1 \mathrm{mM}$ and $0.1-1 \mathrm{mM}$, respectively for 2,4-D. There is a possibility, however, that the sensitivity of the present sensor system can be enhanced by improving the performance of biocatalyst and/or by applying more effective detection method. 


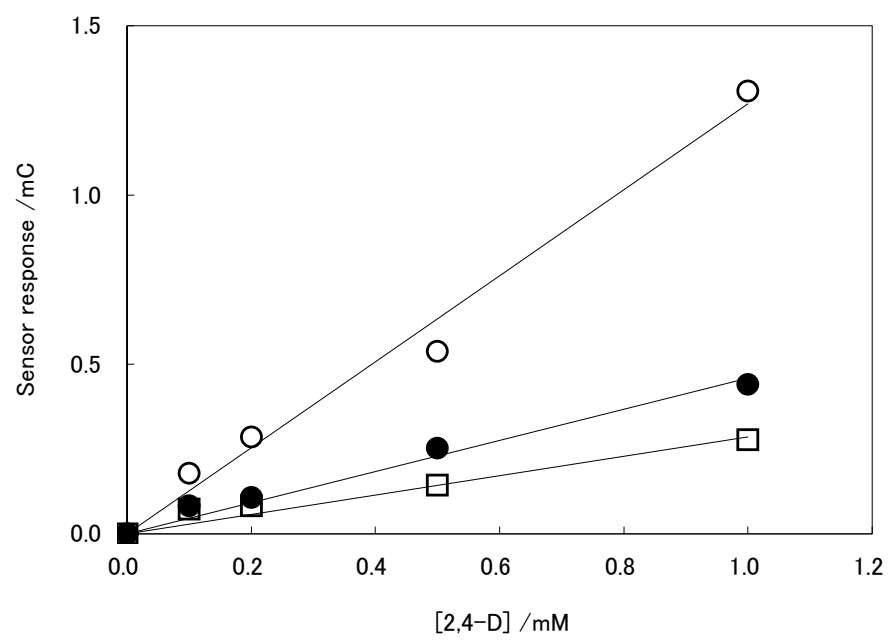

Fig. 12. Effect of the flow rate of carrier solution on sensitivities of the sensor system for 2,4D; (॰) 0.5, (•) 1.0, (口) $2.0 \mathrm{~mL} / \mathrm{min} .(H=12 \mathrm{~mm}, \mathrm{pH} 7.0)$.

\section{Conclusions}

A novel flow-injection biosensor system for 2,4-D detection consisting of the microbial reactor for substrate degradation and the enzyme electrode for product detection was demonstrated. The most remarkable feature of the sensor system is to utilize a 2,4-Ddegrading microorganism such as Ralstonia sp. which produces phenolic compounds at initial stages in the degradation pathway. The 2,4-D degrader was immobilized on silica gel particles and a fixed-bed bioreactor was constructed. The resulting 2,4-DCP and/or 3,5-DCC were detected amperometricaly with the tyrosinase-modified electrode. The sensitivity of the system was found to be considerably affected by $\mathrm{pH}$ and the flow rate of carrier solution. The height of immobilized microorganism bed also exerted reasonable effect on the responsibility. Although the sensitivity is not high enough for microanalysis at the present stage, further improvement of the responsibility is possible. The strategy proposed here can be easily extended to other biosensor development.

\section{References}

Amy, P.S.; Schulke, J.W.; Frazier, L.M.; Seidler, R.J. (1985). Characterization of aquatic bacteria and cloning of genes specifying partial degradation of 2,4dichlorophenoxyacetic acid. Appl. Environ. Microbiol. 49,1237-1245.

Beyersdorf-Radeck, B.; Schmid, R. D. \& Malik, K. A. (1993). Long-term storage of bacterial inoculum for direct use in a microbial biosensor. J. Microbiol. Methods, 18, 33-39.

Bier, F.F.; Ehrentreich-Förster, E.; Dölling, R.; Eremenko, A.V.; Scheller, F.W. (1997). A redox-label immunosensor on basis of a bi-enzyme electrode. Anal. Chim. Acta, 344, 119-124.

Carralero Sanz, V.; Luz Mena, M.; González-Cortés, A.; Yáñez-Sedeño, P. \& Pingarrón, J. M. (2005). Development of a tyrosinase biosensor based on gold nanoparticles- 
modified glassy carbon electrodes. Application to the measurement of a bioelectrochemical polyphenols index in wines. Anal. Chim. Acta, 528, 1-8.

Cavalca, L.; Hartmann, A.; Rouard, N.; Soulas, G. (1999). Diversity of tfdC genes: distribution and polymorphism among 2,4-dichlorophenoxyacetic acid degrading soil bacteria. FEMS Microb. Ecol. 29,45-58.

Dall' Orto, V.C.; Danilowicz, C.; Rezzano, I.; Del Carlo, M.; Mascini, M. (1999). Comparison between three amperometric sensors for phenol determination in olive oil samples. Anal. Lett., 32, 1981-1990.

Don, R.H. \& Pemberton, J.M. (1981). Properties of six pesticide degradation plasmids isolated from Alcaligenes paradoxus and Alcaligenes eutrophus. J. Bacteriol. 145, 681686.

Don, R.H.; Weightman, A.J.; Knackmuss, H.J.; Timmis, K.N. (1985). Transposon mutagenesis and cloning analysis of the pathways for degradation of 2,4-dichlorophenoxyacetic acid and 3-chlorobenzoate in Alcaligenes eutrophus JMP134(pJP4). J. Bacteriol. 161, 85-90.

Fukumori, F. \& Hausinger, R.P. (1993a). Alcaligenes eutrophus JMP134 "2,4dichlorophenoxyacetate monooxygenase" is an a-ketoglutarate-dependent dioxygenase. J. Bacteriol. 175, 2083-2086.

Fukumori, F. \& Hausinger, R.P. (1993b). Purification and characterization of 2,4dichlorophenoxyacetate/ a-ketoglutarate dioxygenase. J. Biol. Chem., 268, 2431124317.

Fulthorpe, R.R., \& Wyndham, R.C. (1992). Involvement of a chlorobenzoate catabolic transposon, Tn5271, in community adaptation to chlorobiphenyl, chloroaniline, and 2,4-dichlorophenoxyacetic acid in a freshwater ecosystem. Appl. Environ. Microbiol. $58,314-325$.

Fulthorpe, R.R.; McGowan, C.; Maltseva, O.V.; Holben, W.H.; Tiedje, J.M. (1995). 2,4Dichlorophenoxyacetic acid-degrading bacteria contain mosaics of catabolic genes. Appl. Environ. Microbiol. 61, 3274-3281.

Gutés, A.; Céspedes, F.; Alegret, S. \& del Valle, M. (2005). Determination of phenolic compounds by a polyphenol oxidase amperometric biosensor and artificial neural network analysis. Biosens. Bioelectron., 20, 1668-1673.

Häggblom, M. M. (1990). Mechanism of bacterial degradation and transformation of chlorinated monoaromatic compounds. J. Basic. Microbiol., 30, 115-141.

Häggblom, M. M. (1992). Microbial breakdown of halogenated aromatic pesticides and related compounds. FEMS Microbiol. Rev., 103, 29-72.

Hianik, T.; Passechnik, V. I. ; Sokolíková, L.; Šnejdárková, M.; Sivák, B.; Fajkus, M.; A.Ivanov, S. \& Fránek, M. (1998). Affinity biosensors based on solid supported lipid membranes. Their structure, physical properties and dynamics. Bioelectrochem. Bioenerg., 47, 47-55.

Hianik, T.; Šnejdárková, M.; Sokolíková, L.; Meszár, E.; Krivánek, R.; Tvarožek, V.; Novotný, I. \& Wang, J. (1999). Immunosensors based on supported lipid membranes, protein films and liposomes modified by antibodies. Sensors and Actuators B, 57, 201-212.

Horáček, J. \& Skládal, P. (1997). Improved direct piezoelectric biosensors operating in liquid solution for the competitive label-free immunoassay of 2,4-dichlorophenoxyacetic acid. Anal. Chim. Acta, 347, 43-50. 
Horáček, J. \& Skládal, P. (2000). Effect of organic solvents on immunoassays of environmental pollutants studied using a piezoelectric biosensor. Anal. Chim. Acta, 412, 37-45.

Itoh, K.; Kanda, R.; Sumita, Y.; Kim, H.; Kamagata, Y.; Suyama, K.; Yamamoto, H.; Hausinger, R.P.; Tiedje, J.M. (2002). tfdA-like genes in 2,4-dichlorophenoxyacetic acid-degrading bacteria belonging to the Bradyrhizobium- AgromonasNitrobacter-Afipia cluster in a-Proteobacteria. Appl. Environ. Microbiol. 68, 34493454 .

Itoh, K.; Tashiro, Y.; Uobe, K.; Kamagata, Y.; Suyama, K. \& Yamamoto, H. (2004). Root nodule Bradyrhizobium spp. harbor $t f d A a$ and $c a d A$, homologous with genes encoding 2,4-dichlorophenoxyacetic acid - degrading proteins. Appl. Environ. Microbiol., 70, 2110-2118.

Ka, J.O.; Holben, W. E. \& Tiedje, J. M. (1994). Genetic and phenotypic diversity of 2,4dichlorophenoxyacetic acd (2,4-D)- degrading bacteria isolated from 2,4-D- treated field soils. Appl. Environ. Microbiol., 60, 1106-1115.

Kaláb, T. \& Skládal, P. (1995). A disposable amperometric immunosensor for 2,4dichlorophenoxyacetic acid. Anal. Chim. Acta, 304, 361-368.

Kamagata, Y.; Fulthorpe, R. R.; Tamura, K.; Takami, H.; Forney, L. J. \& Tiedje, J. M. (1997). Pristine environments harbor a new group of oligotrophic 2,4dichlorophenoxyacetic acid - degrading bacteria. Appl. Environ. Microbiol., 63, 22662272.

Kitagawa, W.; Takami, S.; Miyauchi, K.; Masai, E.; Kamagata, Y.; Tiedje, J. M. \& Fukuda, M. (2002). Novel 2,4-dichlorophenoxyacetic acid degradation genes from oligotrophic Bradyrhizobium sp. strain HW13 isolated from a pristine environment. J. Bacteriol., 184, 509-518.

Laemmli, C.M.; Leveau, J.H.J.; Zehnder, A.J.B.; van der Meer, J.R. (2000). Characterization of a second tfd gene cluster for chlorophenol and chlorocatechol metabolism on plasmid pJP4 in Ralstonia eutropha JMP134(pJP4). J. Bacteriol. 182, 4165-4172.

Lei, Y.; Mulchandani, P.; Chen, W.; Wang, J. \& Mulchandani, A. (2004). Arthrobacter sp. JS443 - based whole cell amperometric biosensor for p-nitrophenol, Electroanalysis, 16, 2030-2034.

Li, J. \& Tan, S.N. (2000). Applications of amperometric silica sol-gel modified enzyme biosensors. Anal. Lett., 33, 1467-1477.

Liu, Z.; Liu, Y.; Yang, H.; Yang, Y.; Shen, G. \& Yu, R. (2005). A phenol biosensor based on immobilizing tyrosinase to modified core-shell magnetic nanoparticles supported at a carbon paste electrode, Anal. Chim. Acta, 533, 3-9.

Mailley, P.; Cummings, E.A.; Mailley, S.; Cosnier, S.; Eggins, B.R. \& McAdams, E. (2004). Amperometric detection of phenolic compounds by polypyrrole-based composite carbon paste electrodes, Bioelectrochemistry, 63, 291-296.

Maltseva, O.; McGowan, C.; Fulthorpe, R.; Oriel, P. (1996). Degradation of 2,4dichlorophenoxyacetic acid by haloalkaliphilic bacteria. Microbiology, 142, 11151122.

Mazzei, F.; Botrè, F.; Montilla, S.; Pilloton, R.; Podestà, E. \& Botrè, C. (2004). Alkaline phosphatase inhibition based electrochemical sensors for the detection of pesticides. J. Electroanal. Chem., 574, 95-100. 
Medyantseva, E. P.; Vertlib, M. G.; Kutyreva, M. P.; Khaldeeva, E. I.; Budnikov, G. K. \& Eremin, S. A. (1997). The specific immunochemical detection of 2,4dichlorophenoxyacetic acid and 2,4,5-trichlorophenoxyacetic acid pesticides by amperometric cholinesterase biosensors. Anal. Chim. Acta, 347, 71-78.

Mosiello, L.; Nencini, L.; Segre, L. \& Spanò, M. (1997). A fibre-optic immunosensor for 2,4dichlorophenoxyacetic acid detection. Sensors and Actuators B, 39, 353-359.

Mulchandani, P.; Hangarter, C. M.; Lei, Y.; Chen, W. \& Mulchandani, A. (2005). Amperometric microbial biosensor for $p$-nitrophenol using Moraxella sp.-modified carbon paste electrode, Biosens. Bioelectron., 21, 523-527.

Notsu, H., Tatsuma, T., Fujishima, A. (2002). Tyrosinase-modified boron-doped diamond electrodes for the determination of phenol derivatives. J. Electroanal. Chem., 523, 8692.

Neilson, J.W.; Josephson, K.L.; Pepper, I.L.; Arnold, R.B.; DiGiovanni, G.D.; Sinclair, N.A. (1994). Frequency of horizontal gene transfer of a large catabolic plasmid (pJP4) in soil. Appl. Environ. Microbiol. 60, 4053-4058.

Notsu, H. \& Tatsuma, T. (2004). Simultaneous determination of phenolic compounds by using a dual enzyme electrodes system, J. Electroanal. Chem., 566, 379-384.

Perkins, E.J.; Gordon, M.P.; Caceres, O.; Lurquin, P.F. (1990). Organization and sequence analysis of the 2,4-dichlorophenol hydroxylase and dichlorocatechol oxidative operons of plasmid pJP4. J. Bacteriol. 172, 2351-2359.

Piras, L.; Adami, M.; Fenu, S.; Dovis, M. \& Nicolini, C. (1996). Immunoenzymatic application of a redox potential biosensor. Anal. Chim. Acta, 335, 127-135.

Rubtsova, M.Y.; Kovba, G. V. \& Egorov, A. M. (1998). Chemiluminescent biosensors based on porous supports with immobilized peroxidase. Biosens. Bioelectron., 13, 75-85.

Serra, B., Reviejo, A.J., Pingarron, J.M. (2003). Flow injection amperometric detection of phenolic compounds at enzyme composite biosensors, Applicatio to their monitoring during industrial waste waters purification processes. Anal. Lett., 36, 1965-1986.

Skládal, P. \& Kaláb, T. (1995). A multichannel immunochemical sensor for determination of 2,4-dichlorophenoxyacetic acid. Anal. Chim. Acta, 316, 73-78.

Suwa, Y.; Wright, A.D.; Fukumori, F.; Nummy, K.A.; Hausinger, R.P.; Holben, W.E.; Forney, L.J. (1996). Characterization of a chromosomally encoded 2,4-dichlorophenoxyacetic acid/ -ketoglutarate dioxygenase from Burkholderia sp. strain RASC. Appl. Environ. Microbiol. 62, 2464-2469.

Stanca, S. E. \& Popescu, I. C. (2004). Phenols monitoring and Hill coefficient evaluation using tyrosinase-based amperometric biosensors, Bioelectrochemistry, 64, 47-52.

Starodub, N. F.; Pirogova, L.V.; Demchenko, A. \& Nabok, A. V. (2005). Antibody immobilisation on the metal and silicon surfaces. The use of self-assembled layers and specific receptors. Bioelectrochemistry, 66, 111-115.

Tonso, N.L.; Matheson, V.G.; Holben, W.E. (1995). Polyphasic characterization of a suite of bacterial isolates capable of degrading 2,4-D. Microb. Ecol. 30, 3-24.

Top, E.M.; Holben, W.E.; Forney, L.J. (1995). Characterization of diverse 2,4dichlorophenoxyacetic acid-degradative plasmids isolated from soil by complementation. Appl. Environ. Microbiol. 61, 1691-1698. 
Trau, D.; Theuerl, T.; Wilmer, M.; Meusel, M. \& Spener, F. (1997). Development of an amperometric flow injection immunoanalysis system for the determination of the herbicide 2,4-dichlorophenoxyacetic acid in water. Biosens. Bioelectron., 12, 499-510.

Vallaeys, T.; Fulthorpe, R.R.; Wright, A.M.; Soulas, G. (1996). The metabolic pathway of 2,4dichlorophenoxyacetic acid degradation involves different families of tfdA and tfdB genes according to PCR-RFLP analysis. FEMS Microb. Ecol. 20, 163-172.

van der Meer, J. R.; de Vos, W. M.; Harayama, S. \& Zehnder, A. J. B. (1992). Molecular Mechanism of genetic adaptation to xenobiotic compounds. Microbiol. Rev., 56, 677694. 


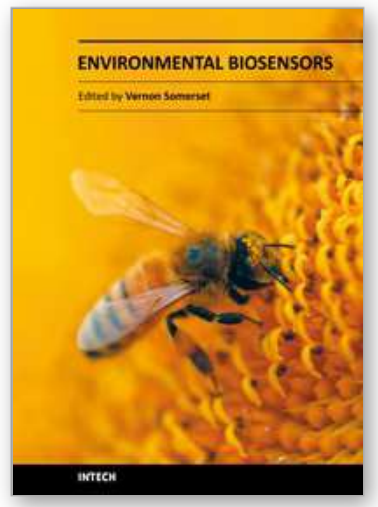

\author{
Environmental Biosensors \\ Edited by Prof. Vernon Somerset
}

ISBN 978-953-307-486-3

Hard cover, 356 pages

Publisher InTech

Published online 18, July, 2011

Published in print edition July, 2011

This book is a collection of contributions from leading specialists on the topic of biosensors for health, environment and biosecurity. It is divided into three sections with headings of current trends and developments; materials design and developments; and detection and monitoring. In the section on current trends and developments, topics such as biosensor applications for environmental and water monitoring, agroindustry applications, and trends in the detection of nerve agents and pesticides are discussed. The section on materials design and developments deals with topics on new materials for biosensor construction, polymerbased microsystems, silicon and silicon-related surfaces for biosensor applications, including hybrid film biosensor systems. Finally, in the detection and monitoring section, the specific topics covered deal with enzyme-based biosensors for phenol detection, ultra-sensitive fluorescence sensors, the determination of biochemical oxygen demand, and sensors for pharmaceutical and environmental analysis.

\title{
How to reference
}

In order to correctly reference this scholarly work, feel free to copy and paste the following:

Mitsuhiro Shimojo, Kei Amada, Hidekazu Koya and Mitsuyasu Kawakami (2011). Flow Injection Biosensor System for 2,4-Dichlorophenoxyacetate Based on a Microbial Reactor and Tyrosinase-modified Electrode, Environmental Biosensors, Prof. Vernon Somerset (Ed.), ISBN: 978-953-307-486-3, InTech, Available from: http://www.intechopen.com/books/environmental-biosensors/flow-injection-biosensor-system-for-2-4dichlorophenoxyacetate-based-on-a-microbial-reactor-and-tyro

\section{INTECH}

open science | open minds

\section{InTech Europe}

University Campus STeP Ri

Slavka Krautzeka 83/A

51000 Rijeka, Croatia

Phone: +385 (51) 770447

Fax: +385 (51) 686166

www.intechopen.com

\section{InTech China}

Unit 405, Office Block, Hotel Equatorial Shanghai

No.65, Yan An Road (West), Shanghai, 200040, China

中国上海市延安西路65号上海国际贵都大饭店办公楼405单元

Phone: +86-21-62489820

Fax: $+86-21-62489821$ 
(C) 2011 The Author(s). Licensee IntechOpen. This chapter is distributed under the terms of the Creative Commons Attribution-NonCommercialShareAlike-3.0 License, which permits use, distribution and reproduction for non-commercial purposes, provided the original is properly cited and derivative works building on this content are distributed under the same license. 